Удк 39(092)Зуб:061(477.83-25)

DOI

ГАУШКО МИХАЙ $О$

Аоктор історичних наук, професор кафеАри етнології Франка. ORCID: https://orcid.org/0000-0003-3520-8891

\title{
HLUSHKO MYKHAILO
}

a Doctor of History, a Professor at the Ivan Franko Lviv National University Ethnology Department. ORCID ID: https://orcid.org/0000-0003-3520-8891

\section{Бібліографічний опис:}

ГАушко, М. (2020) Михайло Зубрицький - Аіямьний член Наукового товариства імені Шевченка у Народна твориість та етнологія, 3 (385), 7-27.

Hlushko, M. (2020) Mykhailo Zubrytskyi as an Active Member of the Shevchenko Scientific Society in Lviv. Folk Art and Ethnology, 3 (385), 7-27.

\section{МИХАЙЛО ЗУБРИЦЬКИЙ - ДІЯЛЬНИЙ ЧЛЕН НАУКОВОГО ТОВАРИСТВА IМЕНI ШЕВЧЕНКА У ЛЬВОВI}

\author{
Анотація / Abstract
}

У статті йдеться про наукову Аіяльність Михайла Зубрицького - відомого українського археографа, історика, етнографа та фольклориста. 3'ясовано історію його вступу до Наукового товариства імені Шевченка у Аьвові (1896), обрання Аійсним членом Товариства (1904) і чиеном Етнографічної комісії (1905), причетність Івана Франка та Михайла Грушевського до цих неординарних Аля священика подій.

Аокладно розглянуто співпрацю М. Зубрицького з різними науково-досліАними піАрозАілами першої української наукової установи. Встановлено: проживаючи у відАаленому віА $\Lambda$ ьвова гірському селі Мшанець, науковець-парох особисто віАвіАав сім засіАань Історично-філософської секції, по оАному разу засіАання Археографічної і Статистичної комісій і Авічі - загальні збори Товариства. На засіАаннях Історично-філософської секції обговорили та рекоменАували Ао Аруку 20 основних Ажерелознавчих, історичних та етнографічних АосліАжень уроАженця Бойківщини, які він піАготував упродовж 1897-1911 років. Членам цього науково-АосліАного піАроздіку сам М. Зубрицький преАставив мише 4 статті, а решту його розвіАок подали інші вчені: І. Франко - 5, М. Грушевський - 6, Володимир Гнатюк - 4, Стефан Томашівський - 1. Тексти підготовлених археографічних та етнографічних досліджень автор часто Аоповнював цікавими фактами навіть піА час їх верстання у друкарні.

М. Зубрицький причетний також до проведення першої комплексної (етнографічно-антропологічної) експедиції українських народознавців (1904). Результати праці ії учасників (І. Франка, Федора Вовка, Зенона Кузелі) вплинули на подальші етнографічні зацікавлення вченого. Зокрема, після завершення цієї наукової манАрівки досліАник активно вивчав народну матеріальну культуру бойків - житло, оАяг і взуття. Із 1904 року він систематично поповнював етнографічні колекції різних музеїв Європи (Етнографічного музею у ВіАні (Австрія), Етнографічного музею у Базелі (Швейцарія), Музею НТШ у Аьвові) цікавими пам’ятками традиційно-побутової культури і народного мистецтва насемення північно-західної частини Бойківщини. 
Кмючові слова: Михайло Зубрицький, Наукове товариство імені Шевченка у Аьвові, Історично-філософська секція, науково-пошукова Аіяльність, збір етнографічних колекцій, Іван Франко, Михайло Грушевський, Володимир Гнатюк.

The article is dedicated to the analyses of the scientific work of Mykhailo Zubrytskyi, a famous Ukrainian archaeographer, historian, ethnographer and folklorist. The history of his entry in the Shevchenko Scientific Society in Lviv (1896), his election as a full member of the Society (1904) and a member of the Ethnographic Commission (1905), Ivan Franko and Mykhailo Hrushevskyi participation in these extraordinary as for the priest events have been revealed.

M. Zubrytskyi collaboration with various research subdivisions of the first Ukrainian scientific institution has been considered in detail. It has been established that he has lived in a mountain village of Mshanets remote from Lviv. Now it belongs to Staryi Sambir district of Lviv region. The scholar-pastor personally has attended seven meetings of the Historical and Philosophical Section, once a meeting of the Archaeographic and Statistical Commissions and twice the General Meeting of the Society.

During the meetings of the Historical and Philosophical Section 20 major source, historical and ethnographic studies of M. Zubrytskyi as a native of Boikivschyna, prepared by him during 1897-1911, have been discussed and recommended for printing. Mykhailo Zubrytskyi has proposed only 4 of his own articles to the members of this research subdivision. The rest of his studies have been prepared by the other scholars: I. Franko - 5, M. Hrushevskyi - 6, Volodymyr Hnatiuk - 4, Stefan Tomashivskyi -1 . The author has often completed the texts of archaeographic and ethnographic researches by interesting facts even in the process of their imposing in the printing house.

M. Zubrytskyi also has been concerned in the realization of the first comprehensive (ethnographic-anthropological) field expedition of Ukrainian ethnographers in 1904. The results of the work of its participants (Ivan Franko, Fedir Vovk, Zenon Kuzelia) have influenced the further ethnographic interests of the scientist.

In particular, the researcher has studied actively the national material culture of Boiky - housing, clothing and footwear after the completion of this scientific journey. Since 1904 he has replenished systematically the ethnographic collections of various museums in Europe (Ethnographic Museum in Vienna (Austria), Ethnographic Museum in Basel (Switzerland), Shevchenko Scientific Society Museum in Lviv) with interesting monuments of traditional and everyday culture of the north-western part of Boikivshchyna.

Keywords: Mykhailo Zubrytskyi, the Shevchenko Scientific Society in Lviv, Historical and Philosophical Section, scientific and research work, ethnographic collections arrangement, Ivan Franko, Mykhailo Hrushevskyi, Volodymyr Hnatiuk.

Михаймо Зубрицький (1856-1919) посіАає особливе місце в історії Наукового товариства імені Шевченка у Аьвові. Проживши бімьшу частину свого життя у віААаленому карпатському семі Мшанець (нині -

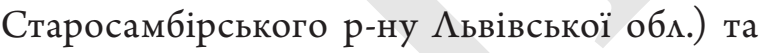
обіймаючи скромну посаду пароха місцевого приходу Української греко-катомицької церкви, він замишив по собі понаА чотири Аесятки наукових праць з археографії, істоpiï, етнографії та фомькмористики, а також майже три сотні публіцистичних (газетних) статей. Зважаючи ще на історичний періоА (кінець XIX - початок XX ст.), коли жив й активно працював учений, інакше як поАвигом назвати цей творчий Аоробок важко.

За роки незалежності України наукова, пубміцистична, суспільно-громадська та Аушпастирська Аіямьність М. Зубрицького вже неодноразово привертала увагу різних фахівців. Вінцем цієї зацікавменості можна вважати нещодавно видане тритомне зібрання творів науковця-пароха та матеріалів про нього [15-17], приурочене Ао 100-річчя 3 Аня його смерті. Саме у Аругому томі цієї збірки опублікувами різні матеріали Ао біографії уродженця Бойківщини (похоАив із с. Кіндратів, нині - Турківського р-ну Аьвівської обм.): автобіографічні, біографічні, фототипію Аокументів приватного архіву, АосиіАження сучасних етнографів, фолькмористів, істориків та мітературознавців про його життєвий шлях і творчу Аіяльність тощо. ОАнак, як засвідчує наш скрупумьозний аналіз, зазначене видання не позбавмене певних прогалин і навіть серйозних неАоміків. ОАин із них - віАсутність окремої грунтовної розвіАки про триваку пліАну співпрацю М. Зубрицького з НТШ у Аьвові [10, c. 640]. Така стаття була би цікком Аоречною, 3 огляду на визначамьний вплив Товариства на формування тематики археографічних, 
історичних, етнографічних і фольклористичних зацікавлень ученого та високу якість його наукової продукції. Саме ці аспекти i посядуть чільне місце в пропонованій статті.

Найперше з'ясуємо одне з найскмаАніших питань - рік і мотиви вступу М. Зубрицького до НТШ у Аьвові. Воно є слушним з тієї причини, що, як ми вже вказували в рецензії на зібрання творів ученого [10, с. 632-633, 640], УПоряАники тритомника, 3 оАного боку, знехтували ним, а з Аругого, - Аопустили значні помилки фактографічного характеру. ІАеться переАусім про безпіАставне тверАження відомого теперішнього канаАського історика українського похоАження, професора Канадського інституту українських студій Університету Альберти Франка Сисина про те, що «стати чменом Наукового Товариства імені Шевченка» М. Зубрицькому запропонував («запросив») особисто М. Грушевський, причому мише в 1904 році [20, с. 36, 46]. ОАнак конкретні факти засвідчують тісні наукові зв'язки і продуктивну співпрацю мшанецького пароха з Товариством задовго до цієї дати.

Щоправда, порівняно з багатьма іншими членами першої української наукової установи, М. Зубрицький вступив Ао неї Аосить пізно - тільки в 1896 році. Показове свідчення цього - запис в обліковій книзі Товариства, у якій його зареєструваци Аише Авісті сорок Аев'ятим (249) членом [5, арк. 84 зв.]. Натомість у списку за 1914 рік Аослідник перебував на обліку вже шістдесят восьмим (68) [6, арк. 34 зв.]. Інакше кажучи, упродовж 18 років членства в науковій організації він перемістився в її обліковій книзі аж на 181 позицію (через смерть частини чменів установи, викмючення з її рядів тих осіб, які не сплачували чменські внески чи порушуваци інші статутні вимоги тощо).

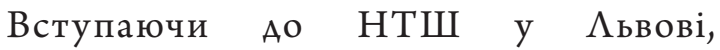
М. Зубрицький також віАзначився неорАинарним вчинком: на відміну віА багатьох інших чменів, він віАразу сплатив значний членський внесок - спершу 10 золотих ринських, а потім ще 41 золотий ринський.
Найважливіше, що обидві суми поповними касу наукової установи в 1896 році [5, арк. 84 зв.], це звіцьнило вченого віА наступних платежів - Ао обрання Аійсним членом Товариства включно. Справа в тому, що в 90-х роках XIX ст. перший (вступний) внесок становив п'ять золотих ринських чи п'ять рублів (Аля преАставників НаААніпрянської України), а щорічний внесок - переважно три золоті ринські (рублі) [5, арк. 23 зв., 25 зв., 29 зв., 69 зв., 71 зв., 80 зв., 103 зв. та ін.].

Конкретні обставини, за яких М. Зубрицький вступив Ао НТШ у через відсутність Аостовірних Аокументацьних свідчень встановити Аосить важко. Це саме стосується особи (осіб), яка спершу схилила уродженця Кіндратова Ао цього кроку, а потім рекомендувала його кандидатуру керівництву Товариства.

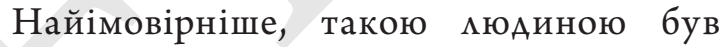
I. Франко, з яким мшанецький парох познайомився і потоваришував ще в 70-х роках XIX ст. - піА час навчання у Арогобицькій гімназії [21, с. 21-22]. Він же першим познайомився із фолькморними записами оАноАітка-священика та використав ї у своїх працях. У $и$ иті до В. Гнатюка віА 11 жовтня 1899 року М. Зубрицький стверАжував, що в 1885 році I. Франко переписав зібрані ним у с. Мшанець коляАки [8, арк. 21]. ТоАі його збірка нараховувала 19 народних творів цього жанру $[19$, с. 231]. ОАну із цих колядок («А що нам било з нащаду світа») I. Франко оприлюАнив у 1889 році в журналі «Киевская старина» $[19$, с. 231-232]. У журналі «Жите і слово» його зусимлями було наАруковано також низку цікавих етнографічних і фольклорних матеріалів мшанецького пароха, зокрема і масштабну за обсягом статтю про його малу батьківщину - «Семо Кіндратів (Турецького пов[іту])» (1895) [15, с. 95-116].

Причетність саме I. Франка Ао вступу М. Зубрицького в Товариство видається нам Ауже ймовірною ще $з$ оАнієї причини. Перші наукові праці («Тісні роки. 
Причинки Ао історії Галичини 18461861 pр.»; «Народний камендар, народні звичаї і повірки, прив'язані до Анів в тижні i до рокових свят (Записані у Мшанці, Староміського повіту і по сусіАніх селах) «Знадоби Аля характеристики життя світського сільського гр[еко-]кат[олицького] Ауховенства в Галицькій Руси в XVIII ст.»), які уродженець Бойківщини опублікував на сторінках різних видань НТШ у $\Lambda$ ьвові («Записки НТШ», «Матеріами Ао українсько-руської етнології, «Матеріали Ао кукьтурної історії Галицької Руси XVIII i XIX віку»), представив (зреферував) на засіАаннях Історично-філософської секції та рекомендував Ао Аруку також він [2, арк. 23, 27, 48; 39, с. 7]. I. Франку намежить і стисла передмова до народного поетичного твору «Віршована фацеція про Аурного Кузьмину» [15, с. 120], уперше опримюАнена в п'ятому томі «Етнографічного збірника» (1898). Ао речі, М. Зубрицький записав цю «фацецию» в 1880 році у с. Кропивник Новий Арогобицького повіту (нині с. Новий Кропивник Арогобицького р-ну $\Lambda$ ьвівської обн.) $[15$, с. 120,122$]$.

Наше припущення вияається не позбавменим сенсу ще й тому, що I. Франко всту-

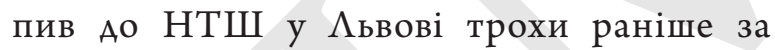
М. Зубрицького - у 1895 році (в обліковій книзі він був зареєстрований Авісті шістнаАцятим (216) чменом [5, арк. 73 зв.]), і своїм прикладом міг спонукати на цей крок також колишнього гімназійного товариша.

Так чи інакше, аме як повноправний чмен НТШ у активізував свою наукову та публіцистичну Аіяльність. За нашими піАрахунками, Аише в 1898-1900 роках у різних виАаннях Товариства він опублікував чотири самостійні наукові розвіАки («Віршована фацеція про Аурного Кузьмину»; «Продажа “попівства” в с. Скопові 1592 р.»; «Тісні роки. Причинки до історії Галичини 18461861 рр.»; «Народний календар, народні звичаї і повірки, прив'язані до Анів в тижні i до рокових свят (Записані у Мшанці,
Староміського повіту і по сусіАніх селах)»), упродовж трьох наступних років - ще п'ять статей («Причинки Ао історії рекрутчини в Галичині при кінці XVIII і до половини XIX століття. Матеріали і замітки»; «Знадоби Аля характеристики життя світського сімьського гр[еко-]кат[олицького] Ауховенства в Галицькій Руси в XVIII ст.»; «Парцеляція війтівства поміж піААаних селян Мшанця 1788 р.»; «Чотири куренАи Аекана Ігната Аавидовича з Радимна 3 А[ня] 9 і 10 мая 1816 р.»; «Кікька Аокументів до історії сільського Ауховенства в Галичині XVII-XVIII в.»). Крім цього, у 1901 році вийшов перший том «Галицькоруських народних приповідок» І. Франка, а в 1902-му - перший том «Галицько-руських народних мегенА», піАготовлений Ао Аруку В. Гнатюком, у яких були оприлюАнені зразки українського фолькмору, зафіксовані зокрема й М. Зубрицьким. Упродовж $1896-$ 1903 років дослідник опублікував 140 повіАоммень і розвіАок у галицьких часописах «Аіло» та «Свобода»: 1896 року - 19 статей, 1897 року - 20, 1898 року - 16, 1899 року - 13, 1900 року - 21, 1901 року - 21, 1902 року - 24, 1903 року - 6 пубцікацій ${ }^{1}$.

Навдивовижу продуктивну наукову i публіцистичну працю мшанецького священика помітило та належно оцінило керівни-

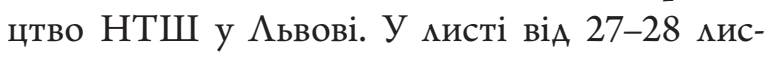
топада 1902 року I. Франко повідомив М. Зубрицькому приємну Аля нього, як міркуємо собі, новину: «У нас повстала гаАка вибрати Вас Аійсним членом історичної секції. Чи могли 6 Ви Аесь колись приїхати на засіАання, от так 2-3 рази Ао року?» [23, с. 218].

У віАповіАі віА 7 груаня 1902 року М. Зубрицький охоче погодився на пропозицію I. Франка: «Сли заіменуєте мене Аійсним членом істор[ичної] секциї, не буду сьому противити ся і скілько буде спромоги і знаня, буду радо причиняти ся Ао спільної праці» [16, с. 288]. Водночас він скаржився аАресату на існування серйозної перешкоди Аля регулярних віАвідин $\Lambda$ ьвова: «Пишете мені, що там в Товаристві поя- 
вила ся гадка іменовати мене Аійсним членом історичної секциї і питаєте ся, чи міг би я 2-3 рази на рік приїхати на засіданя? ВПравАі Аля мене Аосить трУАно ПрихоАить їхати до Аьвова, найбільше через те, що маю кепську Аорогу до зелізниці. Та тепер буде зелізниця іти через Старе-місто, а з віАтам маАять Ао Мшанця повітово-краєву Аорогу, то вже було би Аля мене Аалеко мекше приїхати колись Ао $\Lambda$ ьвова» [16, с. 287-288]. Щоправда, майже через Ава роки (у серпні 1904 р.), вирушаючи в першу комплексну (етнографічно-антропологічну) польову експеАицію, І. Франко, Ф. Вовк та З. Куземя прибули в Мшанець із с. Устріки-Аолішні (нині м. Устрики-Аолішні БещаАського повіту ПіАкарпатського воєвоАства Польської Республіки) [11, с. 14], куди доїхали поїздом.

Питання про обрання М. Зубрицького Аійсним членом Товариства вАруге порушив у кютому 1904 року його голова М. Грушевський, про що АовіАуємося з повіАоммення мшанецького пароха віА 27 мютого цього самого року: «В віАповіАи на Ваше цінне письмо, в якім преАкладаєте мені іменованє мене Аійстним чменом нашого наук[ового] Товариства ім. Шевченка, маю честь донести, що я на се радо годжу ся, бо теперішна робота в нім дуже мені подобає ся, і велика шкода, що така робота у нас бодай з на Ава десятки міт скорше не зачала ся. Та цучше пізно, як ніколи. ОАнак було би Аля мене за тяжко приїзАити на засіАаня секциї 6 разів в році. 3 Мшанця Ао найблизшої станциї замізничої треба їхати три години, а залізницею 5 гоА [ин]. Я вже і обчислив річний виАаток на 180 кор[он], а стілько я видати не могу, бо маю інші конечні видатки. <...> Міг бим

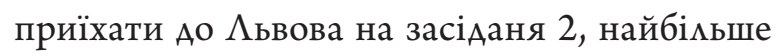
3 рази в році. Наколи се було би Аостаточним, то радо годжу ся на Ваше преАложенє. 3 щирої душі раА бим послужити народній справі», - писав тоді М. Зубрицький голові Товариства [16, с. 265-266].

15 мипня 1904 року відбулося чергове засідання Історично-філософської секції, яке вирішувало мише одне питання - вибір
Аійсних членів НТШ у Цікаво, що учасниками цього засідання були тільки три особи - М. Грушевський, Ф. Вовк і Станіслав Аністрянський, які «одноголосно рішили преАложити видіку на Аійсного чмена секції о. Мих[айла] Зубрицького» [2, арк. 57 зв.]. Запис аналогічного змісту вміщено також у бюметені «Хроніка українсько-руського Наукового товариства

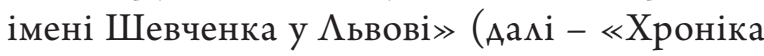
НТШ»): «Вибрано оАноголосно Аійсним чменом о. Михайла Зубрицького, пароха 3 Мшанця, і постановлено преАложити його ВиАілови Ао затверАженя» [42, с. 18].

Президія НТШ У 20 мипня 1904 року і затвердила «вибір о. Михайла Зубрицького у Мшанци на Аійсного чмена іст[орично]-фільософічної секциї» $[42$, с. 15]. Ця сама Аата наявна також у повіАомленні Товариства за № 48, аАресованому особисто М. Зубрицькому: «Наукове Товариство імени Шевченка у Аьвові Аня 20.VII.1904 іменовало Вас, Високоповажаний Аобродію, своїм Аійсним членом в істор[ично-]філосьофічній секції, про що маємо честь Вас сповістити. У

3 обранням Аійсним чменом НТШ у

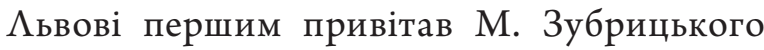
M. Грушевський, зокрема мистом віА 27 мипня 1904 року: «Високоповажаний Отче! Поздоровляю Вас [3] вибором на Аійсного члена Товариства, в історичній секціі. НаАію ся, що віА часу Ао часу загостите на секцію, хоч се Вам і не мегко <...>. Щиро зАоровлю і пишу се з правАивим поважанням» [13, с. 192-193 (фотокопія миста)].

ВіАповіАь М. Зубрицького на привітання голови Товариства була короткою і сповненою слів щирої вАячності за високе визнання його скромного творчого Аоробку: «Свій вибір на Аійстного чмена уважаю великою честію Аля себе і старати ся буду по спро-

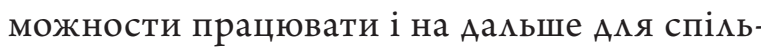
ної нам ціли» [16, с. 267].

Щоправда, як уже зазначалося в нашій рецензії на нещодавно опублікований три- 
томник творів мшанецького пароха, у науковій мітературі існує оАна комізія стосовно конкретного Аня обрання його Аійсним членом Товариства. Маємо на увазі те, що в «Хроніці НТШ» за 1905-й та наступні роки фігурує зовсім інша дата - 29 мипня 1904 року [10, с. 633 (примітка)]. На жамь, цю розбіжність поки що не можемо пояснити.

У наступному, 1905, році М. Зубрицького очікувама ще оАна приємна новина: 13 червня його обрали чменом Етнографічної комісії [43, с. 11] - оАного з найбімьш важмивих i Аієвих науково-досліАних піАрозАілів НТШ У Аьвові першої третини ХХ ст. [9]. Ао речі, того самого Аня цієї честі уАостоїцися також M. Грушевський, Стефан Томашівський, Васимь Аоманицький, 3. Кузеля, Іван Крип'якевич, Аука Гарматій та Володимир Мевинський $[43$, с. 11] - кращі представники української історичної та етнографічної науки початку XX ст.

Як уже знаємо, оАнією з умов обрання М. Зубрицького Аійсним чменом НТШ у Аьвові була його безпосерення участь у роботі Історично-філософської секції. Нагадаємо: у мисті I. Франка йшлося про потребу присутності вченого на засіАаннях цієї спеціамізованої науково-організаційної оАиниці Авічі-тричі на рік, у повіАомленні М. Грушевського - Ао 6 разів. ОАнак, як засвідчують протоколи зібрання членів Історично-філософської секції за 1904-1914 роки, науковець-парох був учасником цих засіАань не наАто часто - усього мише сім разів: 2 мистопада 1904 року [2, арк. 58 зв.], 1 мистопана 1905 року [2, арк. 61], 2 мистопала 1905 року [2, арк. 61 зв.], 2 мютого 1906 року [2, арк. 63], 1 мистопада 1906 року [2, арк. 69 зв.], 30 травня 1907 року [2, арк. 71 зв.] і 31 жовтня 1907 року [2, арк. 73 зв.].

3 архівних Ажерел АовіАуємося також про те, що Авічі М. Зубрицький був присутній на засіданнях інших науково-досліАних піАрозАіків Товариства: Археографічної (1 мистопала 1905 р.) [2, арк. 61 зв.] і Статистичної (1 мистопада 1906 р.) [2, арк. 69] комісій.
Нарешті, Авічі М. Зубрицький був учасником загацьних зборів НТШ у Аьвові: 30 квітня 1907 року [29, с. 6] і 12 травня 1909 року [32, с. 5]. Запрошувами його і на інші зібрання Товариства ${ }^{2}$, але через різні причини, передусім через Аушпастирську Аіяльність, не міг покинути с. Мшанець. Так, неможмивість віАвіАати зібрання чиенів Товариства, яке пианувалося провести 25 березня 1903 року, він пояснив M. Грушевському насампереА нестачею грошей на Аорогу. «Тай тепер вемикий піст, то і бімьше роботи в парохії. Хоть раАбим Ауже поїхати, та годі», - стверАжував парох $[16$, с. 265]. Майже через анамогіч-

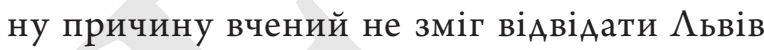
у квітні 1904 року: «Не можу приїхати на наАзвичайні загамьні 3бори нау[кового] Товариства ім. Шевченка, що мають віАбути ся Аня 4. цьвітня с[его] p[оку], бо в тім часі маю богато занятя на парохії» [16, с. 267].

Про ці самі причини М. Зубрицький неодноразово писав також В. Гнатюку: «Я не міг прибути на загамьні збори [19 квітня 1905 р. - М. Г.], то тоді був час вецикого посту, Ае у мене в церкви і парохії більше занятя» (Аист віА 9 жовтня 1905 р.) [8, арк. 25 зв.]; «Тепер [у січні чи на початку мютого 1909 р. M. Г.] я не міг іхати Ао Аьвова, бо якось кінці не сходимися, а Аорога все ж коштує гроша, а вже найгірше, що Ао замізниці віА мене Аосить Аалеко» (повіАомлення віА 10 мютого 1909 р.) [16, с. 257]; «Я не їхав на народний

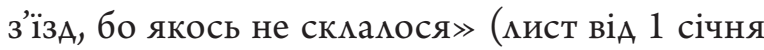
1911 p.) $[16$, c. 259].

Інкоми М. Зубрицький не міг віАвідати $\Lambda$ ьвів 3 інших об'єктивних причин. НаприкмаА, у повіАомкенні Ао М. Грушевського віА 26 груаня 1906 року він пояснював свою відсутність на засіАанні Історично-філософської секції поганим станом зв'язку: «На запрошенє з Аня 18 с[его] м[ісяця] не міг я прибути до Аьвова, позаяк Аотичне письмо відобрав я 3 почти Аоперва 24 с[его] м[ісяця] вечером. ВіА нас ходить післанець на почту мише Ава рази в тижАни, через що посикки часто не в пору прихоАять. 
Прошу проте мою неприсутність виправАати» [16, с. 268].

Беручи участь у роботі загальних зборів Товариства, М. Зубрицький не пас задніх, навпаки, обиАва рази брав слово й вносив власні пропозиції. Зокрема, в оАному 3 випусків «Хроніки НТШ» згаАано про таку його ініціативу: 30 квітня 1907 року «Аійсний чмен, о. Мих[ихаймо] Зубрицький поставив внесенє, щоби загамьні збори ухваАими Поручити новому ВиАінови, з огляАу на Аесятьлітну, повну пожертвованя працю Аля Товариства його дотеперішного голови, проф. Мих[ихайма] Грушевського, пошанувати ії тим, що ВиАіц замовить у котрогось артиста [художника. - М. Г.] портрет голови і примістить його в сали засідань. Внесенє принято оАноголосно без Аискусії» [1, арк. 36 зв.; 29, с. 6]. Наступного разу (12 травня 1909 р.) науковець-парох запропонував не зачитувати протокол попереАніх загацьних зборів, позаяк його вже опубцікували у «Хроніці НТШ» [1, арк. 39 зв.; 32, с. 5].

Зазначені загамьні збори Товариства приховують ще оАин цікавий нюанс з біографії М. Зубрицького. ІАеться про те, що обиАва рази він був наАімений Аодатковим голосом на прохання члена НТШ у Грушевського, пароха Російської православної церкви, яка Аіяла в НаААніпрянській Україні. Про це його право в 1907 році засвіАчує загальний список учасників тогочасного зібрання Товариства [7, арк. 2], у 1909 році зміст повідомлення М. Грушевського віА 4 травня, аАресованого ВиАіку (Президіі)

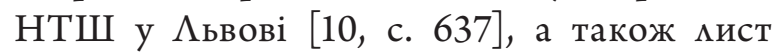
В. Гнатюка до М. Зубрицького віА 5 травня цього самого року [14, с. 301].

Зате жодних відомостей про участь мшанецького пароха в засіАаннях Етнографічної комісії, чменом якої він уважався віА 13 червня 1905 року, поки що не виявмено. Щобільше, на нашу Аумку, сучасні науковці не мають перспектив знайти їх і в майбутньому. Ао цього висновку спонукають нас результати зіставлення Аат (Анів і місяців) проведення зібрань різних спеціацізованих науково-організаційних одиниць і загальних зборів НТШ у Аьвові, учасником яких був М. Зубрицький у 1904-1909 роках, із

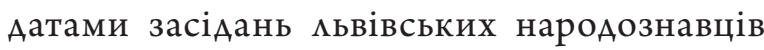
за цей самий періоА. Зокрема, у 1904 році етнографи і фольклористи збиралися Авічі (13 червня, 15 Аипня); у 1905 році - оАин раз (13 червня); у 1906 році - тричі (21 червня, 21 вересня, 7 мистопада); у 1907 році тричі (4 мипня, 26 вересня, 23 груаня); у 1908 році - чотири рази (16 січня, 14 травня, 28 червня, 30 груаня); у 1909 році - чотири рази (25 березня, 6 травня, 24 червня, 9 груАня) [9, с. 331]. Отже, жодна з цих Аат не збігається з раніше визначеними Ан ями перебування вченого у $\Lambda$ ьвові. Інакше кажучи, він не надавав великого значення співпраці із цією структурною оАиницею Товариства.

Зовсім іншим було ставлення М. Зубрицького Ао засіАань Історичнофімософської секції. Як засвідчує зміст иистів уродженця Бойківщини Ао В. Гнатюка, він Аекілька разів просив ученого секрета-

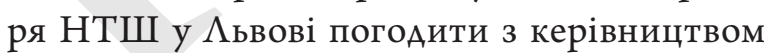
(передусім з М. Грушевським) цього науково-досліАного піАрозАіку зручну Аця нього Аату зібрання. Скажімо, таким способом були узгоджені Ані засіАань Історичнофілософської секції 2 мистопаАа 1904 року, 1 мистопааа 1905 року і 2 мютого 1906 року.

Так про Аату 2 мистопаа 1904 року М. Зубрицький просив В. Гнатюка в мисті віА 23 жовтня 1904 року: «Як є який предмет до обговорення на істор[ично-] фільоз[офічній] секції, то міг бим приїхати 2 падолиста на 10 г[одину] рано до Аьвова, сли буде оголошене засіданє. А ні, то найнаручнійше було би Аля мене в польські різАвяні сьвята приїхати до $\Lambda$ ьвова, бо тог[А]и буде з'їзА Аемокр[атично]-народної партії. ОАнак не міг бим приїхати ані в неАілю, ані сьвято наше, бо в такі Ані мушу бути в церкви» $[16$, с. $255-256]$. Позитивну віАповіАь В. Гнатюка мшанецький парох очікував не наАто довго (аАресат віАписав йому через п’ять Анів - 28 жовтня 1904 р.): «Маю честь П[ана] Т[овариша] чмена повідомити, що 
засіданє Історично-фільос[офічної] секції Наукового Тов[ариства] імені Шевченка буде Аня 2.XI, в середу о годині $101 / 2$ рано 3 таким поряАком:

1. М. Грушевський. Історія України, т. V, ч. I;

2. А[окто $]$ р I. Франко. Матеріали до історії Коліївщини. О гоА[ині] 11 зас[іАання] Археогр[афічної] комісиї» [14, с. 296].

Аналогічно вчений Аомовлявся 3 В. Гнатюкомпро Аату 1 мистопада 1905 року: «Будьте так Аобрі постарати ся о скмиканє істор[ично]-фік[ьософічної] секциї на Аень 1. або 2. падолиста с[ього] р[оку] прим[іром] на 10 гоА[ину] рано. В ті Ані я би приїхав до $\Lambda$ ьвова зі своїми паперами і преАложив секциї Ао осуду. <...> Як буде секция скмикана на поданий мною Аень, то прошу мене повідомити, щоби я знав, чи їхати Ао

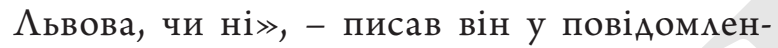
ні віА 9 жовтня 1905 року [8, арк. 25, 26]. Подібним способом бумо узгоджено перебування М. Зубрицького у стінах Товариства 2 ^ютого 1906 року: «Маю намір приїхати Ао $\Lambda$ ьвова 2 юютого, може на той день скмичете засіданє секциї на 3. г[одину] пополуАни, бо вечером хотів бим вертати домів. На той Аень припадає $а$ ат[инське] сьвято, а мабуть і зимові фериї [канікули. - М. Г.], то буауть могми і учите $і$ з провінциї поприїзАити. Рано раА бим свою оруАку власну залагодити у $\Lambda$ ьвові, проте не мав бим часу бути на засіАаню секциї», - писав уродженець Бойківщини до В. Гнатюка 14 січня 1906 року [8, арк. 29-29 зв.]. ААресат не забарився з віАповіААю: «Секція буАе 2/II, як Ви хочете», - констатував він М. Зубрицькому в повідомленні віА 22 січня 1906 року $[14$, c. 297].

ОАнак трапмялися випаАки, коли через різні обставини подібні побажання М. Зубрицького не мали вАалого вирішення. НаприкмаА, у мисті віА 5 травня 1909 рокувін запитував М. Грушевського: «Я викінчую опис селянських будинків в Мшанци і гаАаю ïх взяти з собою, як поїАу на загальні збори. Чи не могмо би в тім часі віАбути ся засіАанє істор[ично-]фіц[вософічної] секциї, на якій би міг сю статю зреферовати? Може би могло стати ся 12 мая о 11 годині рано, або переА 4. пополудни. Сли се буде можмиве, то прошу мене повіАомити віАворотно» $[16$, с. 270].

Проте 12 травня 1909 року чмени Історично-філософської секції не засіда$\Lambda$ и окремо, у зв'язку з чим М. Зубрицький не зміг особисто зреферувати свою статтю «Селянські буАинки в Мшанці, Старосамбірського повіту». Замість нього це зробив В. Гнатюк на засіданні зазначеної спеціалізованої науково-організаційної оАиниці 14 травня 1909 року [2, арк. 89; 32, c. 15], тобто через Ава Ані після провеАення загальних зборів Товариства.

Аля М. Зубрицького, як і Аля інших про-

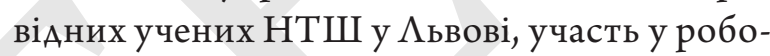
ті Історично-філософської секції мала сенс передусім тому, що саме на їі засіданнях реферували і рекомендували до Аруку наукові праці гуманітарного профілю. Основні Ажерелознавчі, історичні та етнографічні АосліАження уродженця Бойківщини члени цього науково-АосліАного піАрозАіку обговорили в такі Ані: 21 груАня 1898 року [2, арк. 23], 15 мистопада 1899 року [2, арк. 27], 17 жовтня 1900 року [2, арк. 32], 20 квітня 1902 року [2, арк. 45; 38, с. 20], 7 груаня 1902 року [2, арк. 48; 39, с. 7], 1 березня 1903 року [2, арк. 50; 40, с. 10], 10 січня 1904 року [2, арк. 55 зв.; 41, с. 11], 1 мистопада 1905 року [2, арк. 61; 44, с. 6], 3 груАня 1905 року [2, арк. 62; 44, с. 9], 2 мютого 1906 року [2, арк. 63; 27, с. 9], 8 березня 1906 року [2, арк. 63 зв.; 27, с. 11], 1 цистопаАа 1906 року [2, арк. 69 зв.; 28, с. 7], 31 жовтня 1907 року [2, арк. 73 зв.; 30, с. 6], 12 червня 1908 року [2, арк. 79; 31, с. 7], 22 червня 1908 року [2, арк. 79 зв.; 31, с. 10], 14 травня 1909 року [2, арк. 89; 32, с. 15], 14 мипня 1909 року [2, арк. 91 зв.; 32, с. 19], 5 груАня 1909 року [2, арк. 94 зв.; 33, с. 9], 28 червня 1911 року [2, арк. 112 зв.; 35, с. 10] та 8 иистопаАа 1911 року [2, арк. 116; 36, с. 7].

Чотири рази М. Зубрицький особисто виступав на засіданнях Історично- 
філософської секції - 1 иистопада 1905 року [2, арк. 61; 44, с. 6], 2 мютого 1906 року [2, арк. 63; 27, с. 9], 1 иистопаАа 1906 року [2, арк. 69 зв.; 28, с. 7] і 31 жовтня 1907 року [2, арк. 73 зв.; 30, с. 6]. Саме із цієї причини він вмовмяв керівництво першої української наукової установи призначити засіАання спеціалізованої науково-організаційної одиниці Товариства на конкретний день і навіть на певну годину. Про зміст своїх праць, а саме: «Село Мшанець Старосамбірського повіту. Матеріали Ао історії галицького села» (1 мистопада 1905 р.) [2, арк. 61; 44, с. 6], «Велика родина в Мшанці Старосамбірського по[віту]» (2 мютого 1906 р.) [2, арк. 63; 27, с. 9], «Імена, назви і прозвища селян с. Мшанця, Старосамбірського повіту» (1 мистопада 1906 р.) [2, арк. 69 зв.; 28, с. 7] та «Урядові заходи проти холери в 1831 р.» (31 жовтня 1907 р.) [2, арк. 73 зв.; 30, с. 6], учений Аоповів чиенам Історично-філософської секції. Цікаво, що виступ М. Зубрицького про походження і характер документів, які скмали основу його масштабної за обсягом археографічної праці «Село Мшанець Старосамбірського повіту. Матеріали до історії галицького села», слухало аж 10 осіб: М. Грушевський, I. Франко, В. Гнатюк, Кирило Студинський, С. Томашівський, Іван Кревецький, Васимь Герасимчук, Іван Крип'якевич, Роман Закминський та Іван Созанський [2, арк. 61]. На засіданні Історично-фінософської секції 2 мютого 1906 року були присутні М. Грушевський, I. Франко, В. Гнатюк та I. Кревецький [2, арк. 63], на зібранні 1 цистопаАа 1906 року М. Грушевський, I. Франко, I. Кревецький, I. Крип'якевич, Іван АжиАжора і Васимь Щурат [2, арк. 69 зв.], на зборах 31 жовтня 1907 року - М. Грушевський, I. Франко, В. Гнатюк і С. Томашівський [2, арк. 73 зв.].

Решту наукових праць М. Зубрицького преАставлями на зібраннях Історичнофілософської секції інші ї̈ чмени: I. Франко (21 груаня 1898 р.; 15 мистопада 1899 р.; 20 квітня 1902 р.; 7 груАня 1902 р.) [2, арк. 23,
$27,45,48 ; 39$, с. 7], С. Томашівський (17 жовтня 1900 р.) [2, арк. 32], М. Грушевський (1 березня 1903 р.; 10 січня 1904 р.; 12 червня 1908 р.; 22 червня 1908 р.; 14 кипня 1909 р.; 28 червня 1911 р.) [2, арк. 50, 55 зв., 79, 79 зв., 91 зв., 112 зв.; 40, с. 10; 41, с. 11; 31, с. 7, 10; 32, c. 19; 35, с. 10], В. Гнатюк (3 груаня 1905 р.; 8 березня 1906 р.; 14 травня 1909 р.; 5 груАня 1909 р.) [2, арк. 62, 63 зв., 89, 94 зв.; 44, с. $9 ; 27$ с. $11 ; 32$, с. $15 ; 33$, с. 9] та Володимир Охримович (8 Аистопада 1911 р.) [2, арк. 116; 36, c. 7].

Як уже знаємо, I. Франко причетний до публікації у профільних виданнях Товариства перших праць М. Зубрицького, позаяк саме він реферував їхній зміст на засіданнях Історично-філософської секції, а саме: «"Тісні роки”. Причинки Ао історії Галичини 1846-1861 рр.» (21 груАня 1898 р.) [2, арк. 23], «Народний каменAар, народні звичаї і повірки, прив’язані Ао Анів в тижні і до рокових свят (Записані у Мшанці, Староміського повіту і по сусіАніх сенах)» (15 кистопаАа 1899 р.) [2, арк. 27] та «Знадоби Аля характеристики життя світського сімьського гр[еко-]кат[олицького] Ауховенства в Галицькій Руси в XVIII ст.» (7 груаня 1902 р.) [2, арк. 48]. Ао речі, стаття «Тісні роки...» спершу мала дещо іншу назву. У протоколі засіАання цієї секції віА 21 груаня 1898 року іï тогочасний секретар Михайло Павлик зазначив: «Франко реферує материяли Ао голодних часів 1846 i 1847 р. о. Зубрицького <...>. Ухвалено Арукувати в Записках, аме змінити заголовок на “Тісні роки”» [2, арк. 23].

Так, 20 квітня 1902 року I. Франко зреферував зміст ще оАнієї розвіАки М. Зубрицького - «Причинки Ао історії народного шкільництва в Галичині» [2, арк. 45; 38, с. 20]. Як і попереАні статті, іiі також рекомендуваци до Аруку (за пораАою М. Грушевського), зокрема, у «Записках НТШ» [2, арк. 45]. ОАнак I. Франко мав Ао ої змісту серйозні застереження.

У «Хроніці НТШ» іАеться про те, що основоюцієї розвіАки М.Зубрицькомупослу- 
гувала копія «просторого й інтересного Аеканацьного обіжника» віА 1815 року, яким Аоручалося Ауховенству Порохницького Аеканату організовувати парафіяльні церковні школи. I. Франко вважав цей «обіжник враз із иньшими подібними Аокументами <.. > Аобрим причинком Ао історії <..> нар[оАного] шкільництва в початку XIX в.» [38, с. 20], аме, на його Аумку, «у вступі Ао нього намежамо би пояснити бцизше початки тої історії до 1815 р., на кімько вони Аоси вияснені в працях Гемьферта ${ }^{3}$, Гарасевича ${ }^{4}$, Гомовацького ${ }^{5}$, Аевіцького ${ }^{6} \gg$. Свій виступ на засіАанні Історично-філософської секції 20 квітня 1902 року вчений завершив закмиком до подахьшого «збираня і систематичного опублікованя матеріялів Ао історії нашої [української. - М. Г.] сімьської школи переА автономічною ерою, тобто переА р. 1868» $[38$, c. 20$]$.

ПіА час обговорення нового археографічного матеріалу М. Зубрицького виступив також мовознавець Іван Верхратський, який запропонував замість слова «шкільництво» у назві розвіАки вжити який-небуАь інший, бімьш Аоречний термін [2, арк. 45].

Аовідавшись про обговорення статті «Причинки до історії народного шкільництва в Галичині» на засіданні Історичнофілософської секції, М. Зубрицький написав миста I. Франку: «3 Aiла вичитав я, що Ви реферовами в секциї Наук[ового] Товариства ім. Шевченка про переслані мною матеріяли до історії шкімьництва на початку XIX віка. Се мабуть ті матеріяли, які я вислав на адресу А[окто]p[a] В. Гнатюка. Сли так, то мабуть бумо би не зме змучити 3 сим і се, що було поміщене в Аiлi з 1900 р., Ч. 16 піА заголов[ком] “Картина до істориї шкоิмьництва въ Гамичинъ на початку XIX въка”» $\gg 16$, с. 284-285].

ОАнак матеріали цієї розвіАки мшанецького пароха не були опубліковані в «Записках НТШ». Разом із писемними Ажерелами інших Аослінників (І. Франка та Івана Кузіва) вони скмали основу підготовменого I. Франком піАроздіку «Матеріаки
Ао історії гамицького руського шкімьництва в рр. 1801-1848» - частини розАіку «Матеріали Ао історії руського шкільництва 1772-1848» віАомого наукового збірника «Матеріали Ао культурної історії Гамицької Руси XVIII і XIX віку», виАаного зусимиями НТШ у Аьвові в 1902 році. І. Франко як упоряАник цього збірника виАімив писемні Ажерела уродженця Кіндратова окремою назвою - «Чотири куренди Аекана Ігната Аавидовича з Радимна 3 А[ня] 9 і 10 мая 1816 р.» $[15$, с. $207-214]$.

ВіАомий український історик C. Томашівський познайомив чменів Історично-філософської секції зі змістом статті М. Зубрицького «Причинки Ао історії рекрутчини в Галичині при кінці XVIII і Ао половини XIX століття. Матеріали і замітки» (17 жовтня 1900 р.) [2, арк. 32]. Аумка про іiі піАготовку визріла у мшанецького АосліАника в 1899 році піА час опрацювання різних писемних Аокументів, виявлених у семян Бойківщини. У $и$ иті Ао В. Гнатюка віА 28 груаня 1899 року він так писав про цю іАею: «При переписованю паперів найшов я оАин, Ае семянин жалує ся, що громаАа напосіма ся на него і хоче змовити єго сина і відаати до війська. Ае Аамі найшло ся бімьше таких і подібних паперів. ТогАи почав я випитовати мюАий і АовіАав ся, як Аавнійше

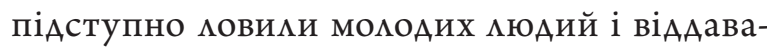
ми в рекрути. 3 зібраного материялу раА бим зАожити розвіАку про рекрутчину віА часу занятя Галичини Австрією Ао 1850 р. Коми з тим упораю ся, вишлю Ао Вас Ао Записок» [8, арк. 22 зв.]. Цією самою іАеєю АосиіАник подімився також 3 I. Франком, зокрема в повіАомленні віА 24 січня 1900 року: «Наміряю також написати розвіАку про початок рекрутчини в Гамичині в початках австрийського панованя. Маю оАну пісню записану, кімька оповідань, як мовими молоАців і як они ховами ся, а також кімька старих паперів, Аотикаючих сего предмету. Коми розвіАка буде готова, вишмю Ао Вас Аля зреферованя на засіданю секциї» $[16$, с. 279]. Отже, зважаючи на зазначену раніше Аату 
преАставлення цього АосліАження у стінах Товариства, можемо стверАжувати, що наА його піАготовкою М. Зубрицький працював Аосить Аовго - щонайменше рік.

Шість статей науковця-пароха зреферував М. Грушевський: «Кімька Аокументів Ао історії сімьського Ауховенства в Галичині XVII-XVIII в.» (1 березня 1903 р.) [2, арк. 50; 40, с. 10], «Годівмя, купно і продаж овець у Мшанці Старосамбірського повіту» (10 січня 1904 р.) [2, арк. 55 зв.; 41, c 11], «Галицькі священики в Хоммщині» (12 червня 1908 р.) [2, арк. 79; 31, с. 7], «Причинки Ао історії руського Ауховенства в Гамичині віА 1820-1853 р.» (22 червня 1908 р.) [2, арк. 79 зв.; 31, с. 10], «Аеканамьні й парохіямьні бібміотеки Перемиської єпархї̈ (14 мипня 1909 р.) [2, арк. 91 зв.; 32, c. 19], «Канонічний огмяА парохії Ріпник в Короснянськім деканаті в Галичині в 1780 р.» (28 червня 1911 р.) [2, арк. 112 зв.; 35, c. 10]. Як засвіАчують іхні назви, п'ять із них маки археографічний та історичний характер і стосувалися церковної тематики українців Галичини та Хоммщини. Ао речі, у процесі піАготовки Ао Аруку назву останньої статті М. Зубрицького частково віАкоригуваки, позаяк у протокомі засіАання Історичнофілософської секції віА 28 червня 1911 року вона зазначена трохи інакше: «Канонічна візитація парохії Ріпник в Короснянськім Аеканаті в Гахичині в 1780 р.» [2, арк. 112 зв.; 35 , с. 10]. Тоді ж члени секції прийнями ще одне важииве рішення: «Просити автора, щоби зміст візитації використав в самій розвіАці, не наводячи іiі in exfenco [повністю. -

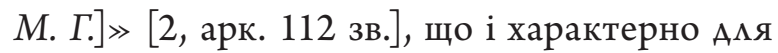
остаточного варіанта цієї розвіАки.

Натомість вихіА статті «ГодівАя, купно і продаж овець у Мшанці Старосамбірського повіту > супровоАжувався неприємними Аля М. Зубрицького перипетіями. ЗгіАно зі змістом його миста Ао Президії Товариства віА 5 мютого 1904 року, хтось із чменів наукової установи повіАомив йому, що на засіАанні Історично-філософської секції цю його працю розгАяАа и піА назвою, віАмінною віА авторської: «При кінци груАня м[инулого] p [оку] вислав я на адресу А. Гнатюка свою працю п[iА ] заголовком “ГоАівля, купно іпроАаж овець в Мшанци”. Ся праця бума обговорена на засіданю істор[ично]-фімьозофічної секциї піА зміненим наголовком: “Хов овець на ПіАгірю”. На мою Аумку слово “хов” у нас не уживане, а ховати не значить годовати. На маА “гоАів я" уживають $ю$ юи бімьше слів, як торговля, зимівця, рахівця. Сю мою увагу прошу переказати тому, хто займе ся реАакциєю сих моїх записок» [3, арк. 7].

Як уже знаємо, зміст цієї статті реферував М. Грушевський, який насправАі озаглавив іiі Аещо інакше, ніж стверАжується у процитованому фрагменті повіАомлення М. Зубрицького, - «Про гоАівлю овець у Старосамбірщині» $[41$, с. 11]. Члени Історично-філософської секції рекоменауваки етнографічну розвіАку мшанецького пароха Ао Аруку в «Матеріялах до українсько-руської етнологї̈. Опубцікуваки їі в шостому томі цього виАання, віАновивши первісну назву - «ГоАівмя, купно і продаж овець у Мшанці старосамбірського повіту»

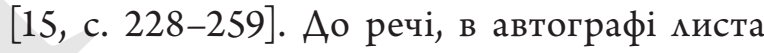
M. Зубрицького навпроти тексту про проблеми 3 назвою цього його АосліАження омівцем написано: «Не змінено» [3, арк. 7].

Чотири етнографічні статті М. Зубрицького представив членам Історичнофілософської секції В. Гнатюк: «Пачкарство бакуну (тютюну) в горах у Галичині в XIX ст.» (3 груаня 1905 р.) [2, арк. 62; 44, c. 9]; «Верхня вовняна ноша українськоруського народу в Гамичині (8 березня 1906 р.) [2, арк. 63 зв.; 27, с. 11]; «Семянські буаинки в Мшанці, Старосамбірського повіту» (14 травня 1909 р.) [2, арк. 89; 32, с. 15]; «Ходаки, обув семян Старосамбірського і Турчанського повіту» (5 груаня 1909 р.) [2, арк. 94 зв.; 33, с. 9]. ЩоправАа, зазначені назви статей набуми завершамьного вигмяду піА час піАготовки їх Ао Аруку, позаяк у протокомах засіАань цієї науково-організаційної оАиниці Товариства частина з них має Аещо інші назви: «Верхня вовняна ноша україн- 
сько-руського народу в горах у Галичині $>[2$, арк. 63 зв.; 27, с. 11], «Семянські будинки в Мшанці» [2, арк. 94 зв.; 32, с. 15], «Ходаки» [2, арк. $89 ; 33$, с. 9].

Нарешті, В. Охримович зреферував розвіАку М. Зубрицького «Маєтковий стан селян у Мшанці Старосамбірського повіту в 1910 р.» (8 кистопада 1911 р.) [2, арк. 116; 36, с. 7], яку опублікувани у спеціалізованому збірнику Товариства «Студії з помя суспільних наук і статистики» в 1912 році [16, с. 573-577]. Крім цього, В. Охримович повторно АоповіАав про неї на засіАанні Статистичної комісії (15 мистопада 1911 р.) [2, арк. $118 ; 36$, с. 18], оскімьки саме чмени зазначеного науково-досліАного піАроздіку НТШ у Аьвові опікувалися цим збірником. Стаття «Маєтковий стан семян...» була останньою прижиттєвою науковою працею мшанецького пароха.

Загалом же, за нашими піАрахунками, чиени Історично-фінософської секції обговорили зміст АваАцяти наукових статей М. Зубрицького, які він підготував упроАовж 1897-1911 років ${ }^{7}$. Їх кількість - це майже половина всього наукового доробку вченого (без записів фольклорних матеріаАів, що до своїх видань вкАючили І. Франко та В. Гнатюк). Ці праці посідають особливе місце не мише у творчості уродженця Кіндратова, аме й в українській археографічній, історичній та етнографічній науці загацом, позаяк віАзначаються новизною та високою якістю. Ао речі, статті, які складають іншу половину наукового Аоробку мшанецького пароха, він опубцікував або Ао вступу в НТШ у Аьвові, або це короткі археографічні розвідки, оприлюднені на сторінках «Записок НТШ» (у рубриці «Miscellanea») без спеціаньного обговорення на зібраннях Історично-фінософської секції. Зокрема, Ао цієї категорії публікацій намежать такі матеріали М. Зубрицького: «Продажа “попівства” в с. Скопові 1592 р.» (1898) [15, с. 123-124], «Парцемяція війтівства поміж підАаних села Мшанця 1788 р.» (1902) [15, c. 203-206], «Парохіяни віАмовмяють піА- писів на петицію против відобрання церковних і парохіяльних Аібр в 1848 р.» (1904) [17, с. 907-908], «Помічні Ані. Причинки Ао історії панщини в Галичині в XIX в.» (1904) $[15$, с. 225-227] та «ВіАкиик австрійського уряду за добровіньними жертвами на війну (В 50 Аітну річницю битви піА МаАжентою)» (1909) [15, с. 514-515].

Розмову про опубціковані на сторінках

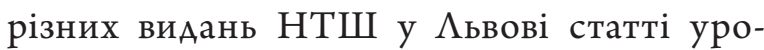
Аженця Бойківщини завершимо цікавими фактами, що ілюструють його науковий пошук. Зокрема, як засвідчує кистування М. Зубрицького 3 Аіяльними чменами Товариства, він неодноразово Аоповнював

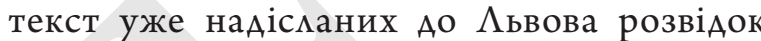
новими фактами, вносив певні корективи в їхній зміст тощо.

Показовий приклаА - Аоповнення статті «Годівля, купно і продаж овець у Мшанці старосамбірського повіту» новими етнографічними матеріалами. Так, У мисті до ПрезиАії Товариства віА 5 мютого 1904 року науковець-парох стверАжував: «Через недогляА не написав я нічого про трумбету, так важний інструмент [музичний. - М. Г.] у вівчарів. Теперь пересимаю уступ про трумбету на 3 картках $a$, 6, в Ао Аолученя Ао моєї праці. Уступ про трумбету має прийти зараз по вівчарських сьпіванках. Посилаю також 1 картку про продаж 103 овець; в горі назначено, Ае він має прийти» [3, арк. 7-7 зв.]. Ф. Вовк як віАповіАальний реАактор шостого тому «Матеріялів до українсько-руської етнології», у якому наАрукува и зазначену статтю, в рахував це прохання М. Зубрицького Аише частково, подавши відомості про музичний інструмент наприкінці статті у формі Аодатка та озаглавивши його одним словом - «Трумбета» [15, с. 258-259]. Зате Аокументальне свідчення 1776 року про продаж 103 овець віАповіАальний реАактор «Матеріялів...» розмістив у зазначеному автором місці - у піАзаголовку «Продаж купчих овець», після слів «А тесть повіАат: “Якось то Бог Аасть”» [15, с. 257-258]. 
Інший приклаА. У рукопису вступної частини до збірки документів, опублікованих у масштабній статті «Семо Мшанець Старосамбірського повіту. Матеріали до історії галицького села», М. Зубрицький Аопустив незначну неточність, яку вирішив виправити по гарячих сліАах (як уже йшлося раніше, текст цієї праці історик преАставив особисто на засіданні Історичнофікософської секції 1 иистопааа 1905 р.): «В моїм переАнім слові Ао збірки зараз 3 початку я написав, що ФеАьо Цмай, мшанецький газАа, спалив купу старих паперів серед хати і они горіки як субітка. ОАнак се не точно. Як раз недавно оповідав він мені знов про се, аме повів, що в печи спамив і горімо, як субітка. Будьте так добрі і се місце справте», - писав він В. Гнатюку в повідомленні від 1 грудня 1905 року [8, арк. 28-28 зв.]. ААресат сумлінно виконав прохання вченого, позаяк у переАмові до Аокументів цієї його праці читаємо: «Тутешний газда Цмаїв Федьо оповідав недавно, що прикиикав старого Аяка, виніс 3 комори ціку купу паперів і Аав йому прочитати. Він щось трохи віАложив на бік, а решту вкинули в піч і запалили, "горіло так, як субітка"» [15, с. 293].

Новими етнографічними матеріалами Аоповнив М. Зубрицький і рукопис піАготовленої Ао Аруку статті «Велика роАина в Мшанці Старосамбірського пов[iту]»: «По віАосланю збірки материялів на Вашу аАресу мені пощастило ще Аещо видобути віА мужиків і то досить цікавого. ОАнак не віАсилаю теперь, бо сподію ся в най коротшім часі ще віА трьох газАів дещо видобути і переписати. Коли все буде готове і упорядковане, привезу ао ьвова, або, як не буде можлива їзАа, відошлю. Маю намір приїхати Ао

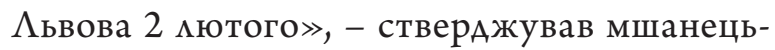
кий парох у мисті Ао В. Гнатюка віА 14 січня 1906 року [8, арк. 29].

Словом, М. Зубрицький постійно перебував у творчому пошуку - допоки та чи інша підготовмена ним наукова стаття не виходима Аруком.
Уродженець Кіндратова мав безпосереАній стосунок ще Ао оАнієї неординарної події в історії української науки. ІАеться про першу комплексну (етнографічно-антропологічну) польову експедицію українських народознавців, яку влітку 1904 року організувало НТШ у Аьвові й частково профінансувамо Австрійське народознавче товариство. М. Зубрицький причетний Ао цієї наукової мандрівки тим, що їі чмени I. Франко, Ф. Вовк та 3. Кузеля проживали й харчувалися понаА тижАень У його оселі. У Аомівці науковцяпароха Ф. Вовк проводив антропологічні обміри місцевих селян [11, с. 14$]$.

Перебування провіАних українських народознавців у помешканні М. Зубрицького та можиивість обговорювати 3 ними різні Аослідницькі проблеми, зокрема 3 ділянки етнографії, потім позначимися на тематиці його наукових студій. Принаймні наші попереАники не зауважили, що саме після комплексної експеАиції 1904 року вчений почав активно збирати польові етнографічні відомості про традиційну матеріальну культуру місцевих бойків - про будівництво, оАяг та взуття. Так постали три відомі його статті: «Верхня вовняна ноша українськоруського народу в Галичині $>(1908)$, «Семянські будинки в Мшанці, Старосамбірського повіту» (1909) та «ХоАаки, обув селян Старосамбірського і Турчанського повіту» (1909).

На відміну віА археографічних, історичних, фолькмористичних та етнографічних розвіАок із Ауховної культури, піАготовка наукового досліАження із народної матеріальної культури віАзначається оАнією особливістю - описи конкретних об'єктів житма чи оАягу, знаряАь праці чи посуду тощо обов'язково Аоповнюють ілюстративними матеріалами (манюнки чи світлини), що, зрозуміло, ускиаднює й уповіньнює науковий процес. Через це часто-густо затримується Арук самих праць. Така ситуація скмалася і з працями М. Зубрицького, які стосувалися традиційної матеріальної культури автохтонів північно-захіАної частини Бойківщини. 
НаприкмаА, статтю «Верхня вовняна ноша українсько-руського народу в Галичині» чиени Історично-фінософської секції обговорими 8 березня 1906 року, але у світ вона вийшла мише в 1908 році, тобто щонайменше через Ава роки. А все тому, що текст треба було Аоповнити якісними ілюстраціями. Чцени науково-АосліАного піАрозАіку «заблокували» їі Арук доти, поки автор не виконає їхн рішення - не «пришле потрібні ААя сеї статі рисунки» [2, арк. 63 зв.]. Ще раніше (22 січня 1906 р.) про цю необхіАність особисто інформував М. Зубрицького В. Гнатюк: «Праця про ношу не йАе Ао збірника, бо до неї конечно треба малюнків і то Аобрих. <...> Треба казати пофотографувати серАаки, а потім наАрукуємо працю в “Матеріалах до укр[аїнсько]-р[уської] етно$\Lambda$ ьогіі” $\gg[14$, с. 297].

В. Гнатюк обговорював із М. Зубрицьким проблеми ілюстрування етнографічних матеріалів, які стосувалися Ауховної культури карпатського населення. Так, у иисті віА 31 січня 1911 року, піАтверАивши уроАженцю Кіндратова отримання його рукопису про похоронні звичаї та обряди в с. Мшанець, В. Гнатюк запитував у колеги: «Чи не можна би Ао нього поробити ще Аеяких рисунків або фотографій? Було би гарно, а кошти покрило 6 Товариство, бо вони ж не були би великі. Прошу подумати наА тим» $[14$, с. 302$]$. У наступному $и$ исті (віА 20 Аютого 1911 р.) В. Гнатюк АоАатково уточнив Аеякі нюанси стосовно ілюстративного матеріалу Ао цих етнографічних Ажерем: «Мамюнки не конечно мусять бути 3 Мшанця, аме й $з$ инших місцевостий на Бойківщині. Може Ви будете коли в Старім Самборі та поговорики 6 з тамошним парохом, чи при нагоді якого похорону не можна би поробити фотографій або рисунків з отаких сцен <...>: 1) Мерлець на маві; 2) Мерця несуть; 3) Читання євангелії; 4) Проща; 5) Гостина по похороні. Якби була ще яка сцена цікавіша, то також їі втягнути (прим[іром,] коли 6 домовину везми саньми вАіті) $\gg[14$, с. 302$]$.
Прохання В. Гнатюка М. Зубрицький задовольнив Аише частково, подавши Ао опису похоронних звичаїв та обряАів бойків малюнки Аомовини Авох типів - із «горбатим» і «глаАким» (пласким) віками [15, с. 555].

Із взаємного Аистування М. Зубрицького та В. Гнатюка АовіАуємося також про те, що графічні зображення різних об’єктів матеріальної культури автохтонів Бойківщини були виконані на замовмення Етнографічного музею 3 м. Базеля (Швейцарія). Щонайважливіше, у повідомменні віА 23 мютого 1910 року науковецьпарох згадав автора малюнків: «Ті рисунки виготовияа Аонька мого сусіАа і я хотів би зробити з них віАбитки. Чи не зробити би се у $\Lambda$ ьвові, чи де се робить ся, якби я їх переслав до Вас?» - запитував він В. Гнатюка $[16$, c. 258]. Ааці М. Зубрицький перерахував усі малюнки, які Аочка сусіАа виготовила Аля швейцарського музею: «Сіньський воАяний млин (модель $є$ у музеї у Вас), загорода (віАбитка є у Матеріялах), пиуг, “шеліжки”, возок до спущеня мотузя (модель у вас), жорна, Арабний віз (модель у музеї), копиця сіна, кік зі снопами, чоловік сівач, миинок Ао чищенє імьну, ступа, скмадові частини воза, ярмо. ОАна відбитка мишила би ся у Вас у музеї, а Аругу я би післав Ао Базелю, а оригінам Ви би мені вернули», - писав тоді етнограф В. Гнатюку [16, с. 258].

Конкретне ім'я «доньки сусіАа», пароха із с. Галівка (нині - Старосамбірського р-ну $\Lambda$ ьвівської обл.), яка виготовила мамюнки на його замовмення, М. Зубрицький назвав у статті «Семянські будинки в Мшанці, Старосамбірського повіту». Звали цю нароАну художницю Асею Господаревською [15, c. 493]. Крім цього, як стверджував автор зазначеної розвіАки, частину наявних у ній графічних зображень виконав Михайло Пирожинський, колишній народний учитель с. Мшанець [15, с. 493]. Зусимлями саме А. Господаревської та М. Пирожинського були проілюстровані, найімовірніше, й інші статті мшанецького пароха із традиційної матеріальної культури бойків: «ГоАівля, 
купно і продаж овець у Мшанці старосамбірського повіту» та «Ходаки, обув селян Старосамбірського і Турчанського повіту».

Мовмячи про пиіАну співпрацю М. Зубрицького з НТШ у можемо обійти стороною і його участь у формуванні етнографічних колекцій різних музеїв Європи. Зауважимо: цим видом робо-

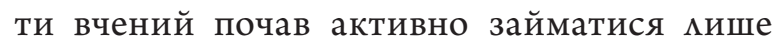
після комплексної народознавчої експеАиції 1904 року. Зокрема, уперше про моделі об'єктів народної культури бойків, призначені Аля Музею етнографії у ВіАні, науковецьпарох згадав у иисті до I. Франка віА 27 мютого 1905 року: «Вчера ПрихоАив сюАи [АО М. Зубрицького. - М. Г.] Роман Петричкович, майстер моде $і$ ів і велів Вам написати, що вже все зробив, а се 19 штук і просить, щоби Ви собі се забрами. Не знаю, як се зробите. Як би схотіки сюАи приїхати, то Аайте знати на сей четвер, я вишлю фіру і теплу одіж, бо у нас ще велика зима, місцями межить сніг по на 2 мет[ри] і більше» [16, с. 288].

I. Франко не забарився з віАповіААю: «Тепер не можу приїхати, аме прошу маскаво змагодити реєстрик речей, зроблених Вашим майстром, і прислати мені, а я порозуміюся 3 проф. Вовком і з віденським музеєм і постараюся о гроші», - писав він М. Зубрицькому 1 березня 1905 року [24].

Реєстр виготовцених майстром Р. Петричковичем моделей охоплював селянську садибу, засоби первинної обробки сільськогоспоАарської продукції, знаряААя праці та зразки сухопутного транспорту, а саме:
«2 обійстя 100 кор.
2 ткацькі верстати 40 [кор.]
2 жорна 20 [кор.]
2 точика 4 [кор.]
2 волові вози 20 [кор.]
2 сани 8 [кор.]
2 ніжні ступки 4 [кор.]
2 візки мотузя спущати 4 [кор.]
2 стікьці вісні 4 [кор.]
2 плуги з теліжками 16 [кор.]
1 миинок мен миинковати 3 [кор.]
На скрині до опакованя 10 [кор.]

разом 231 [кор.]

задаток 5 [кор.]

мишає ся 226 [кор.]

По одержаню тих гроший він [майстер. - М. Г.] віАставить свій товар вмасним коштом до Устрік, а за перевіз з Устрік до ьвова заплатите Ви самі», - наголосив М. Зубрицький I. Франку в повідомиенні віА 7 березня 1905 року [16, с. 288-289].

Процитоване викликає наукове зацікавмення з Авох причин. По-перше, у поданому мшанецьким парохом списку фігурують конкретні вироби з дерева, макети яких виготовив місцевий майстер. По-Аруге, за винятком оАного експоната (млинка Аця переробки насіння $\Lambda$ ьону), усі макети він виготовив у Авох екземплярах: оАин Аля Етнографічного музею у ВіАні, Аругий Аля Ф. Вовка. Про замовцення макета кожної зазначеної вище

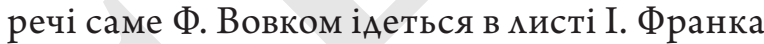
Ао М. Зубрицького віА 1 березня 1905 року, про що вже була мова, а також у його повіАомленні до самого Ф. Вовка віА 4 вересня 1905 року: «Щодо моделів, то я раАив би піАожАати, поки не поїдемо в гори до Мшанця. Бойко поплаче та й перестане, мише напишіть о. Зубрицькому, що приїдемо, гроші привеземо і вироби заберемо. Се його заспокоїть» [26].

М. Зубрицький 1 травня 1906 року знову нагадав I. Франку про народного умікьця та виготовлені ним моделі різних приладів: «При нагоді прошу Вас памятати на майстра Романа Петричковича та про його вироби Ао музеум. Може би Ви як видусили віА Німців гроші, а зроблені річи забрали Аля пересилки Ао ВіАня» [16, с. 291].

Згодом (25 мипня 1906 р.) це саме питання порушив В. Гнатюк у мисті до Ф. Вовка: «Я бачився з А[окторами] Иукою Гарматієм ${ }^{8}$, I. Попемем ${ }^{9}$ і М. Зубрицьким; усі вони мають Аля Вас якісь преАмети, то закуплені, то зроблені на замовлення; порозумійтеся з ними, куди мають їх доставити, бо вони хотіки 6 їх позбутися» $[18$, с. 59].

Загалом оплата за виготовлені Р. Петричковичем макети об'єктів традиційної мате- 
ріацьної культури бойків затрималася аж до пізньої осені 1906 року. Аише 7 мистопада I. Франко надіслав М. Зубрицькому належні за них гроші: «Отсе Аістав гроші та й гаАав їхати до Мшанця, але кмопіт, що в мене часу і здоров'я мало. То вже, будьте маскаві, Аопоможіть розвязатися з тим Аіком. Посикаю Вам переказом 100 ринських (200 кор[он]) і прошу Вас вислати модемі до ВіАня» [25, c. 300].

M. Зубрицький виконав прохання I. Франка, віАправивши до ВіАня макети мшанецького майстра, що піАтверАжує його Аист Ао Аиректора Етнографічного музею Міхаемя Габерландта віА 16 мистопада 1906 року [16, c. 297-298]. Через Ава Ані (18 листопаАа) науковець-парох інформував про цю поАію особисто I. Франка: «На Ваше порученя 3 7. с [его] м[ісяця] вислано моделі піА поданою Вами аАресою Аня 15. с[его] м[ісяця] Ао ВіАня. Всіх преАметів було 10, я попривязовав картки [з мегендами. - М. Г.], а майстер спаковав в Аві скрині, віАвіз до Устрік і надав оплатно. Рахунок підписаний майстром посикаю Вам, весь видаток виносить 158 кор[он] 23 с[отки], назаА віАсикаю Вам 41 кор [ону] 77 сот[ок] переказом. Рівночасно висилаю повідомменє Ао дотичного музея у ВіАни, що віАси вислано моделі на Ваше припорученє, аби там знали, яка посилка Ао них приходить» [16, с. 291]. Уже 28 мистопаАа цього самого року М. Габерланат повідомив I. Франка: «Сьогодні з Мшанця надійшли 10 цікавих моделей, що виготовив селянин Роман Петричкович. Я пацко й маскаво Аякую Вам, високоповажний Пане Аокторе, за Ваше мюб'язне й успішне посереАництво, а також за Ваші зусиция; сердечно прошу Вас повіАомити, яку вартість скмаАають кошти виготовлення і кому мені їх сліА наАіслати» $[12$, с. 231]. Так завершилася тривака епопея із закупівлею дерев'яних макетів різних преАметів траАиційно-побутової культури населення Бойківщини Аля Етнографічного музею у ВіАні.

Стосовно іншої частини виготовмених мшанецьким майстром моделей, то їхня Аоля поки що невіАома. Принаймні сереА колекцій сучасного Російського етнографічного музею, що в Санкт-Петербурзі, які свого часу активно допомагав формувати $\Phi$. Вовк, вироби сікьського умільця із с. Мшанець не виявАяємо. Натомість різні оригінальні преАмети (частина ткацького верстата, веретено, Аерев'яний посуА, компоненти чоловічого і жіночого оАягу, зразки народної вишивки, ткані рушники, прикраси, іграшки, музичні інструменти тощо - загалом 259 експонатів), які вчений зібрав у 1904-1905 роках на території Бойківщини (Мшанець, Аютовиська,

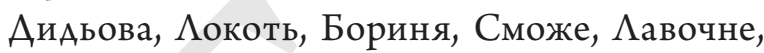
Славське, Тухия, Головецько, Пиав'я, Гребенів, Сколе, Бряза (нині - с. Козаківка Аолинського р-ну Івано-Франківської обц.) та інші поселення), становцять одну з важкивих етнографічних колекцій (№ 1653) цього сучасного науково-кумьтурного осереАку Російської Федерації [22, с. 19].

М. Зубрицький причетний Ао поповнення преАметами народної кумьтури бой-

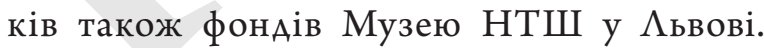
3 обопільного мистування В. Гнатюка та М. Зубрицького АовіАуємося про те, що спершу вчений секретар Товариства просив Аушпастиря приАбати Аля етнографічної колекції наукової установи «модель нароАної будівлі» [14, с. 298]. У повідомленні віА 5 березня 1909 року він знову повторив це прохання, а також замовив інші речі: «НаАто прошу призбирати бойківську ношу на Ава манекіни, мужчину і женщину, маючи на увазі при тім річи, що виходять із уживання» [14, с. 298]. Уже 16 червня цього самого року М. Зубрицький інформував В. Гнатюка про успішне виконання замов-

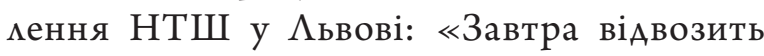
наш майстер замовлений модемь мшанецького обійстя, ношу чоловіка і жінки і образ “Страшний СуА”, про який Ви Ао мене ще Аавнійше писали. В скринці межи одежію $€$ образ сьв[ятого] Николая, який також посимаю до музею» [8, арк. 20].

Крім того, 27 січня 1910 року

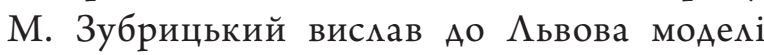


інших об'єктів траАиційно-побутової культури автохтонів с. Мшанець [4, арк. 1]: місцевої церкви, водяного миина, жорен, верстата, «Арабинястого воза волового 3 ярмом», «візка мотузя спускати», ручної ступи, ножної ступи, «млинка Ао млинкованя $\iota$ ьону», точима $[34$, с. 26]. ЩоправАа, Товариство не спішило розраховуватися 3 майстром за виконану роботу, оскільки через місяць (28 Аютого 1910 р.) парох був змушений нагадувати науковій установі про нього: «Аня 27/1 с[ього] р[оку] вислав я через зек[ізничну] стацїю в Устріках моделі церкви в Мшанци, мкина, воза і т., а рівночасно вислав рахунок майстра, що все те змаАив, почтою, на що дотеперь не відобрав я ніякої віАповіАи. Рахунок майстра виказував 220 кор. і сю суму прошу вислати як найскорше, щоби заспокоїти мужика, який віА часу Ао часу приходить Ао мене і Аопитуєть ся, чи прийшки гроші?» [4, арк. 1].

I все ж, незважаючи на подібні недоречності, М. Зубрицький не припиняв компцектувати фонди Музею НТШ у Аьвові новими народними пам'ятками. У звіті цього науково-організаційного піАрозАіку за травень - серпень 1913 року стверАЖується, що вчений приАбав ААя нього 78 нових преАметів. Усі вони стосувацися переробки мьону, конопель і ткання полотна: «ламавка, мечик, мапка до мапаня $\Lambda$ ьну і конопемь; <..> висікачка-мечик, мапка Ао висіканя пазАіря з мьону й конопемь; $<\ldots>$ щіть до чесаня прядива; <...> куделя 3 пряАивом; <...> веретено при куАелі; <...> мотовило Ао мотаня прядених ниток; <..> віявки, кАючки, ків віА віявки; <...> шпуяяр, патак (колісце на зелізнім Ароті, скринка); $<. .>$ бич до обертаня шпуляра; <...> ціва велика, вкладаєть ся на шпуляр; <...> Арабинка; <...> сновальниця до снованя основи; <...> огнива; <...> предмети <..>, які творять великі старі кросна» [37, с. 21].

Нарешті, завАяки М. Зубрицькому в 1911 році Аесяток бойківських експонатів (ножна ступа, ручна ступа, ярмо, жорна, сільничка, пкуг, вика та ін.) поповники фонди Етнографічного музею у м. Базелі (Швейцарія) [16, с. 293-295].

Отже, проживаючи у віААаленому віА $\Lambda$ ьвова карпатському селі Мшанець й обіймаючи скромну посаду пароха місцевого приходу Української греко-католицької церви, М. Зубрицький був оАним з найбільш Аієвих і поважних співробітників НТШ у $\Lambda$ ьвові наприкінці XIX - на початку XX ст. Вступивши до Товариства (1896), він відразу активізував свою науковопошукову та пубціцистичну роботу, що згодом стало піАставою авторитетним ученим установи обрати його Аійсним чменом Історично-філософської секції (1904) та членом Етнографічної комісії (1905). Набувши найвище тогочасне наукове звання, М. Зубрицький виправдовував його своєю щоденною пиіАною працею на ниві української археографії, історії, етнографії та фолькмористики: з одного боку, участю у засіАаннях Історично-філософської секції та інших науково-організаційних підроздіків Товариства, а також у загальних зборах його чменів, з Аругого, - піАготовкою і публікацією в різних фахових виАаннях НТШ у Аьвові («Записки НТШ», «Матеріали до українсько-руської етномогії), «Етнографічний збірник» та ін.) Аесятків статей і розвідок, які неодноразово ставали об'єктом пимьної уваги його колег - членів Історично-фімософської секції. М. Зубрицький безпосереАньо причетний Ао проведення першої в українському народознавстві комплексної (етнографічно-антропологічної) експедиції та формування етнографічних колекцій різних музеїв (Етнографічного музею у ВіАні, Музею НТШ у Аьвові, Етнографічного музею у Базелі), до яких увійшки й автентичні зразки (а також їні моделі) традиційної матеріальної культури і народного мистецтва бойків. 


\section{Примітки}

${ }^{1}$ Усі зазначені дані підраховано за виданням «Михайло Зубрицький. Зібрані твори і матеріали» [Аив.: 17, c. 14-25].

2 Упродовж 1904-1914 років відбулося шість загальних зборів НТШ у Аьвові: 29 червня 1904 року, 19 квітня 1905 року, 30 квітня 1907 року, 12 травня 1909 року, 5 червня 1911 року, 29 червня 1913 року [Аив.: 1, арк. 19-48].

${ }^{3}$ І Аеться, напевно, про австрійського історика й політичного Аіяча Йосипа-Олександра Гельферта (1820-?).

4 I. Франко згадує Михайла Гарасевича (1763$1836)$ - українського історика і церковного діяча.

${ }^{5}$ Яків Головацький (1814-1888) - український етнограф, фольклорист, історик, громадський Аіяч, педагог.

${ }^{6}$ Мабуть, I. Франко мав на увазі Костя Аевицького (1859-1941) - відомого українського вченого і державного Аіяча.
7 Першу дату встановцено на основі повідомиення М. Зубрицького Ао М. Грушевського віА 1 груАня 1897 року, у якому вперше мовиться про конкретний Аокумент (грамоту «на парохію Скопів Перемиської єпархії), призначений Аля Аруку в «Записках НТШ» [16, с. 263]. 8 мистопада 1911 року на засіданні Історично-філософської секції обговорили останню самостійну наукову працю М. Зубрицького «Маєтковий стан селян у Мшанці Старосамбірського повіту в 1910 р.», про що вже йшиося.

${ }^{8}$ Аука Гарматій (1866-1924) - український етнограф, фольклорист, педагог.

${ }^{9}$ Іван Попемь (?-?) - священик, який збирав етнографічні матеріали до фундаментальної праці «Гуцульщина» Володимира Шухевича.

\section{Список використаних Ажерем}

1. Центральний Аержавний історичний архів Украї-

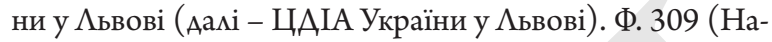
укове товариство ім. Шевченка). Оп. 1. Спр. 31 (Протоколи загальних зборів. 1903-1940рр.). 96 арк.

2. ЦАІА України у риство ім. Шевченка). Оп. 1. Спр. 42 (Протоколи засіАань Історично-фікософської секції товариства. 19031915 рр.). 141 арк.

3. ЦАІА України у Аьвові. Ф. 309 (Наукове товариство ім. Шевченка). Оп. 1. Спр. 204 (Аистування з чиенами товариства, вчителями та приватними особами про видання наукових праць, пересилку мітератури, виплату гонорарів та ін., т. VI. 1904 р.). 46 арк.

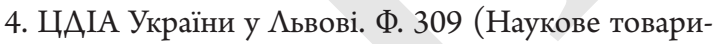
ство ім. Шевченка). Оп. 1. Спр. 210 (Аистування з чиенами товариства, вчитемями та приватними особами про видання наукових праць, пересилку мітератури, виплату гонорарів та ін., т. V. 1910 р.). 16 арк.

5. ЦАІА України у Аьвові. Ф. 309 (Наукове товариство ім. Шевченка). Оп. 1. Спр. 371 (Книга обліку Аійсних чиенів товариства, т. I. 1873-1920рр.). 145 арк.

6. ЦАІА України у Аьвові. Ф. 309 (Наукове товариство ім. Шевченка). Оп. 1. Спр. 374 (Книга обміку чиенів товариства. 1914 р.). 135 арк.

7. ЦАІА України у ьвові. Ф. 309 (Наукове товариство ім. Шевченка). Оп. 1. Спр. 375 (Список чиенів правління товариства, присутніх на загальних зборах 30 травня 1907 р.). 2 арк.

8. ЦАІА України у ство ім. Шевченка). Оп. 1. Спр. 2271 (Аисти Р. Загайкевича, Р. Заклинського, М. Зубрицького та інших Ао В. Гнатюка). 35 арк.
9. ГАушко М. Етнографічна комісія Наукового товариства імені Шевченка у Аьвові (1898-1940): персональний склаА, функції. Арогобицький краєзнавчий збірник. Арогобич : Посвіт, 2019. Вип. XXI. С. 317-348.

10. ГАушко М. [Рецензія] Зубрицький М. Зібрані твори і матеріали : у 3 т. / реАкол.: Франк Сисин (голова) та ін. Аьвів : Аітопис, 2013. Т. 1 : Наукові праці. 609 с. ; 2016. Т. 2 : Матеріали до біографії. 613 с. ; 2019. Т. 3 : Газетні публікації, етнографічні та архівні матеріали. 1023 с. Записки Наукового товариства імені Шевченка. Аьвів, 2019. Т. CCLXXII : Праці Філологічної секції. C. 628-647.

11. Гцушко М. Перша комплексна наукова експеАиція українських народознавців. Народна творчість та етнологія. 2019. №. 5. С. 11-25.

12. Горак Р., Зимомря М., Зимомря І. Аисти Міхаемя Габерляндта до Івана Франка. Українське літературознавство. Аьвів, 2019. Вип. 84. С. 211-235.

13. Аем'ян Г. Маловідомі сторінки життя і наукової праці Михайла Зубрицького. Записки Наукового товариства імені Шевченка. Аьвів, 1992. Т. ССХXIII : Праці секції етнографії та фолькмористики. С. 172-196.

14. Аем'ян Г. Аисти Володимира Гнатюка до Михайла Зубрицького. Записки Наукового товариства імені Шевченка. Аьвів, 1992. Т. ССХХІІІ: Праці Секції етнографії та фольклористики. С. 293-308.

15. Зубрицький М. Зібрані твори і матеріали : у 3 т. / реАкол.: Франк Сисин (голова) та ін. Аьвів : Аітопис, 2013. Т. 1 : Наукові праці. 609 с.

16. Зубрицький М. Зібрані твори і матеріали : у 3 т. /

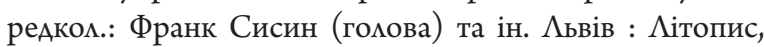
2016. Т. 2 : Матеріали до біографії. 613 с. 
17. Зубрицький М. Зібрані твори і матеріали : у 3 т. / редкол.: Франк Сисин (голова) та ін. Аьвів : Аітопис, 2019. Т. 3 : Газетні пубмікації, етнографічні та архівні матеріали. $1023 \mathrm{c}$.

18. Аистування Федора Вовка з Володимиром Гнатюком / передм. В. Наулка ; упоряА. та ком. В. Наулка, Н. Руденко , О. Франко. Аьвів ; Київ, 2001. 215 с.

19. Миронъ [Франко I.]. Замъчательныя комядки. Киевскал старина. 1889. ГоА 8. Т. XXIV. Кн. I (Январь). C. 231-233.

20. Сисин Ф. Михайло Зубрицький: Аітописець бойківської верховини. Зубрицький М. Зібрані твори і матеріали : у 3 m. / реАкол.: Франк Сисин (голова) та ін.

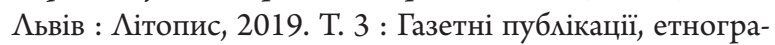
фічні та архівні матеріали. С. 35-55.

21. Сисин Ф. Отець Михайло Зубрицький: Нестор українського сема. Зубрицький М. Зібрані твори іматеріали : y 3 m. / редкол.: Франк Сисин (голова) та ін. Аьвів : Аітопис, 2013. Т. 1 : Наукові праці. С. 15-41.

22. Украинцы : каталог-указатемь этнографических комекций. XIX-XX вв. / Государственный музей этнографии народов СССР ; сост. Н. М. Хазова, О. В. Карпова. АенинграА, 1983. 64 с.

23. Франко I. Ао М. I. Зубрицького [Аьвів, 2728 мистопада 1902 р.]. Франко I. Зібрання творів : $50 \mathrm{~m}$. Київ : Наукова думка, 1986. Т. 50 : Аисти (1895-1916). C. 217-218.

24. Франко I. Ао М. І. Зубрицького. [ $А$ ьвів], 1 березня 1905 р. Франко І. Зібрання творів : у 50 m. Київ : Наукова Аумка, 1986. Т. 50 : Аисти (1895-1916). С. 264-265.

25. Франко I. Ао М. І. Зубрицького. [Аьвів], 7 мистопада 1906 р. Франко I. Зібрання творів : у 50 m. Київ : Наукова думка, 1986. Т. 50 : Аисти (1895-1916). С.300-301.

26. Франко I. Ао Ф. К. Вовка. Берегомет, 4 вересня 1905 р. Франко І. Зібрання творів : у 50 m. Київ : Наукова Аумка, 1986. Т. 50 : Аисти (1895-1916). С. 274.

27. Хроніка Наукового Товариства імени Шевченка у Аьвові. [Аьвів], 1906. Ч. 26. Вип. II : Справозданє за місяці: січень - цьвітень. 25 с.

28. Хроніка Наукового Товариства імени Шевченка у Аьвові. [Аьвів], 1906. Ч. 28. Вип. IV : Справозданє за місяці: вересень - грудень. 22 с.

29. Хроніка Наукового Товариства імени Шевченка у Аьвові. [Аьвів], 1907. Ч. 31. Вип. III : Справозданє за місяці: май - серпень. 40 с.
30. Хроніка Наукового Товариства імени Шевченка у Аьвові. [Аьвів], 1907. Ч. 32. Вип. IV : Справозданє за місяці: вересень - грудень. 32 с.

31. Хроніка Наукового Товариства імени Шевченка у Аьвові. [Аьвів], 1908. Ч. 35. Вип. III : Справозданє за місяці: май - серпень. 44 с.

32. Хроніка Наукового Товариства імени Шевченка у Аьвові. [Аьвів], 1909. Ч. 39. Вип. III : СправозАанє за місяці: май - серпень. $51 \mathrm{c}$.

33. Хроніка Наукового Товариства імени Шевченка у Аьвові. [Аьвів], 1909. Ч. 40. Вип. IV : Справозданє за місяці: вересень - грудень. 45 с.

34. Хроніка Наукового Товариства імени Шевченка у Аьвові. [Аьвів], 1910. Ч. 42. Вип. II : Справозданє за місяці: січень - цвітень. $31 \mathrm{c.}$

35. Хроніка Наукового Товариства імени Шевченка

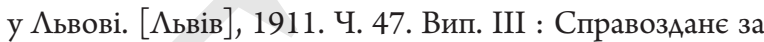
місяці: май - серпень. 24 с.

36. Хроніка Наукового Товариства імени Шевченка у місяці: вересень-грудень. 37 с.

37. Хроніка Наукового Товариства імени Шевченка у місяці: май - серпень. 31 с.

38. Хроніка українсько-руського Наукового Товариства імени Шевченка у Аьвові. [Аьвів $],$ 1902. Ч. 10. Вип. II : 1902, січень - цьвітень. 39 с.

39. Хроніка українсько-руського Наукового Товариства імени Шевченка у Аьвові. [Аьвів], 1902. Ч. 12 Вип. IV : 1902, вересень - грудень. 26 с.

40. Хроніка українсько-руського Наукового Това-

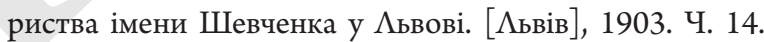
Вип. II : 1903, січень - цьвітень. 27 с.

41. Хроніка українсько-руського Наукового Товариства імени Шевченка у Аьвові. [Аьвів $],$ 1904. Ч. 18. Вип. II : 1904, січень - цьвітень. 27 с.

42. Хроніка українсько-руського Наукового Товариства імени Шевченка у Аьвові. [Аьвів $], 1904$. Ч. 19. Вип. III : 1904, май - серпень. 30 c.

43. Хроніка українсько-руського Наукового Товариства імени Шевченка у Аьвові. [Аьвів], 1905. Ч. 23. Вип. III : Аругий квартал: май - серпень. 18 с.

44. Хроніка українсько-руського Наукового Товариства імени Шевченка у Аьвові. [Аьвів], 1905. Ч. 24. Вип. IV : Третій квартал: вересень - грудень. 35 с.

\section{References}

1. Central State Historical Archives of Ukraine in Lviv. Fund 309 (T. Shevchenko Scientific Society), inventory 1, dossier 31 (Proceedings of General Meeting. 1903-1940), 96 folios [in Ukrainian].

2. Central State Historical Archives of Ukraine in Lviv. Fund 309 (T. Shevchenko Scientific Society), inventory 1, dossier 42 (Proceedings of the Meeting of Historical and Philosophical Section of the Society. 1903-1915), 141 folios [in Ukrainian].

3. Central State Historical Archives of Ukraine in Lviv. Fund 309 (T. Shevchenko Scientific Society), inventory 1, dossier 204 (Correspondence with the Society Members, 
Teachers and Private Persons about the Publication of Scientific Works, Literature Sending and Fees Payment, etc., volume 6, 1904), 46 folios [in Ukrainian].

4. Central State Historical Archives of Ukraine in Lviv. Fund 309 (T. Shevchenko Scientific Society), inventory 1, dossier 210 (Correspondence with the Society Members, Teachers and Private Persons about the Publication of Scientific Works, Literature Sending and Fees Payment, etc., volume 5, 1910), 16 folios [in Ukrainian].

5. Central State Historical Archives of Ukraine in Lviv. Fund 309 (Shevchenko Scientific Society), inventory 1, dossier 371 (A Book of Registration of the Full Members of the Society, vol. 1, 1873-1920), 145 folios [in Ukrainian].

6. Central State Historical Archives of Ukraine in Lviv. Fund 309 (Shevchenko Scientific Society), inventory 1, dossier 374 (A Book of Registration of the Full Members of the Society, 1914), 135 folios [in Ukrainian].

7. Central State Historical Archives of Ukraine in Lviv. Fund 309 (Shevchenko Scientific Society), inventory 1, dossier 375 (The List of Members of the Society Board Present at the General Meeting on May 30, 1907), 2 folios [in Ukrainian].

8. Central State Historical Archives of Ukraine in Lviv. Fund 309 (Shevchenko Scientific Society), inventory 1, dossier 2271 (Letters of R. Zahaikevych, R. Zaklynskyi, M. Zubrytskyi and others to V. Hnatiuk), 35 folios [in Ukrainian].

9. HLUSHKO, Mykhailo. Ethnographic Commission of the Shevchenko Scientific Society in Lviv (1898-1940): Personal Complement, Functions. Drohobych Regional Studies Collection. Drohobych: Posvit, 2019, issue 21, pp. 317-348 [in Ukrainian].

10. HLUSHKO, Mykhailo. [Review] Mykhailo Zubrytskyi. Collected Works and Materials: In Three Volumes / Frank SYSYN (editorial board chief). Lviv: Litopys, 2013, vol. 1: Scientific Works, 609 pp.; 2016, vol. 2: Materials for the Biography, 613 pp.; 2019, vol. 3: Newspaper Articles, Ethnographic Works and Archival Materials, 1023 pp. Proceedings of the Shevchenko Scientific Society. Lviv, vol. 272: Works of Philological Section, pp. 628-647.

11. HLUSHKO, Mykhailo. The First Comprehensive Scientific Expedition of Ukrainian Ethnologists. Folk Art and Ethnology, 2019, 5, 11-25 [in Ukrainian]. https://doi. org/10.15407/nte2019.05.011.

12. HORAK, Roman, Mykola ZYMOMRIA, Ivan ZYMOMRIA. The Letters of Michael Haberlandt to Ivan Franko. Ukrainian Literary Studies. Lviv, 2019, issue 84, pp. 211-235 [in Ukrainian].

13. DEMIYAN, Hryhoriy. Little Known Pages of Life and Scientific Work of Mykhailo Zubrytskyi. Proceedings of the T. Shevchenko Scientific Society. Lviv, 1992, vol. 223: The Works of Ethnography and Folkloristics Section, pp. 172196 [in Ukrainian].

14. DEMIYAN, Hryhoriy. Volodymyr Hnatiuk Letters to Mykhailo Zubrytskyi. Proceedings of the T. Shevchenko Scientific Society. Lviv, 1993, vol. 223: The Works of Eth- nography and Folkloristics Section, pp. 293-308 [in Ukrainian].

15. SYSYN, Frank, the editorial board's chairperson. ZUBRYTSKYI, Mykhailo. Collected Works and Materials: In Three Volumes. Lviv: Litopys, 2013, vol. 1: Scientific Works, 609 pp. [in Ukrainian].

16. SYSYN, Frank, the editorial board's chairperson. ZUBRYTSKYI, Mykhailo. Collected Works and Materials: In Three Volumes. Lviv: Litopys, 2016, vol. 2: Materials for Biography, 613 pp. [in Ukrainian].

17. SYSYN, Frank, the editorial board's chairperson. ZUBRYTSKYI, Mykhailo. Collected Works and Materials: In Three Volumes. Lviv: Litopys, 2019, vol. 3: Newspaper Published Works, Ethnographic and Archival Materials, 1023 pp. [in Ukrainian].

18. NAULKO, Vsevolod, Nataliya RUDENKO, Oksana FRANKO, compilers. Correspondence of Fedir Vovk and Volodymyr Hnatiuk. Lviv; Kyiv, 2001, 215 pp. [in Ukrainian].

19. MYRON (FRANKO, Ivan). Splendid Koliadki. Kievskaya starina, 1889, Year 8, vol. 24, book 1 (January), pp. 231-233 [in Ukrainian].

20. SYSYN, Frank, the editorial board's chairperson. ZUBRYTSKYI, Mykhailo. Collected Works and Materials: In Three Volumes. Lviv: Litopys, 2019, vol. 3: Newspaper Published Works, Ethnographic and Archival Materials, pp. 35-55 [in Ukrainian].

21. SYSYN, Frank. Father Mykhailo Zubrytskyi; Nestor of the Ukrainian Village. In: SYSYN, Frank, the editorial board's chairperson. ZUBRYTSKYI, Mykhailo. Collected Works and Materials: In Three Volumes. Lviv: Litopys, 2013, vol. 1: Scientific Works, pp. 15-41 [in Ukrainian].

22. KHAZOVA, Nataliya, Olga KARPOVA. Ukrainians: Catalogue-Reference Book of Ethnographic Collections. 19-20 Centuries. Leningrad, State Museum of Ethnography of the USSR nations, 1983, 64 pp. [in Russian].

23. FRANKO, Ivan. To M. I. Zubrytskyi [Lviv, November 27-28, 1902]. In: BERNSHTEIN, Mykhailo, editorin-chief. I. FRANKO. Collected Works: In Fifty Volumes. Vol. 50: Letters (1895-1916). Kyiv: Naukova dumka, 1986, pp. 217-218 [in Ukrainian].

24. FRANKO, Ivan. To M. I. Zubrytskyi [Lviv], Mach 1, 1905. In: BERNSHTEIN, Mykhailo, editor-in-chief. I. FRANKO. Collected Works: In Fifty Volumes. Vol. 50: Letters (1895-1916). Kyiv: Naukova dumka, 1986, pp. 264 265 [in Ukrainian].

25. FRANKO, Ivan. To M. I. Zubrytskyi [Lviv], November 7, 1906. In: BERNSHTEIN, Mykhailo, editorin-chief. I. FRANKO. Collected Works: In Fifty Volumes. Vol. 50: Letters (1895-1916). Kyiv: Naukova dumka, 1986, pp. 300-301 [in Ukrainian].

26. FRANKO, Ivan. To F. K. Vovk. Berehomet, September 4, 1905. In: BERNSHTEIN, Mykhailo, editor-in-chief. I. FRANKO. Collected Works: In Fifty Volumes. Vol. 50: Letters (1895-1916). Kyiv: Naukova dumka, 1986, pp. 274 [in Ukrainian]. 
27. Chronicle of the Shevchenko Scientific Society in Lviv. [Lviv], 1906 part 26, issue 2: Report for January-April, 25 pp. [in Ukrainian].

28. Chronicle of the Shevchenko Scientific Society in Lviv. [Lviv], 1906, part 28, issue 4: Report for September-December, 22 pp. [in Ukrainian].

29. Chronicle of the Shevchenko Scientific Society in Lviv. [Lviv], 1907, part 31, issue 3: Report for May-August, 40 pp. [in Ukrainian].

30. Chronicle of the Shevchenko Scientific Society in Lviv. [Lviv], 1907, part 32, issue 4: Report for September-December, 32 pp. [in Ukrainian].

31. Chronicle of the Shevchenko Scientific Society in Lviv. [Lviv], 1908, part 35, issue 3: Report for May-August, 44 pp. [in Ukrainian].

32. Chronicle of the Shevchenko Scientific Society in Lviv. [Lviv], 1909, part 39, issue 3: Report for May-August, 51 pp. [in Ukrainian].

33. Chronicle of the Shevchenko Scientific Society in Lviv. [Lviv], 1909, part 40, issue 4: Report for September-December, 45 pp. [in Ukrainian].

34. Chronicle of the Shevchenko Scientific Society in Lviv. [Lviv], 1910, part 42, issue 2: Report for January-April, 31 pp. [in Ukrainian].

35. Chronicle of the Shevchenko Scientific Society in Lviv. [Lviv], 1911, part 47, issue 3: Report for May-August, 24 pp. [in Ukrainian].
36. Chronicle of the Shevchenko Scientific Society in Lviv. [Lviv], 1911, part 48, issue 4: Report for September-December, 37 pp. [in Ukrainian].

37. Chronicle of the Shevchenko Scientific Society in Lviv. [Lviv], 1913, part 55, issue 3: Report for May-August, 31 pp. [in Ukrainian].

38. Chronicle of the Ukrainian-Ruthenian Shevchenko Scientific Society in Lviv. [Lviv], 1902, part 10, issue 2: 1902, January-April, 39 pp. [in Ukrainian].

39. Chronicle of the Ukrainian-Ruthenian Shevchenko Scientific Society in Lviv. [Lviv], 1902, part 12, issue 4: 1902, September-December, 26 pp. [in Ukrainian].

40. Chronicle of the Ukrainian-Ruthenian Shevchenko Scientific Society in Lviv. [Lviv], 1903, part 14, issue 2: 1903 January-April, 27 pp. [in Ukrainian].

41. Chronicle of the Ukrainian-Ruthenian Shevchenko Scientific Society in Lviv. [Lviv], 1904, part 18, issue 2: 1904: January-April, 27 pp. [in Ukrainian].

42. Chronicle of the Ukrainian-Ruthenian Shevchenko Scientific Society in Lviv. [Lviv], 1904, part 19, issue 3: 1904, May-August, 30 pp. [in Ukrainian].

43. Chronicle of the Ukrainian-Ruthenian Shevchenko Scientific Society in Lviv. [Lviv], 1905, part 23, issue 3: The Second Quarter: May-August, 18 pp. [in Ukrainian].

44. Chronicle of the Ukrainian-Ruthenian Shevchenko Scientific Society in Lviv. [Lviv], 1905, part 24, issue 4: The Third Quarter: September-December, 35 pp. [in Ukrainian]. 